UDC 81'42:328.131

DOI https://doi.org/10.32838/2663-6069/2020.2-2/13

Humeniuk N. H.

Borys Grinchenko Kyiv University

\title{
STYLISTIC ASPECT OF THE BORIS JOHNSONS REALIZATION OF THE DISCREDITING OPPONENT TACTICS WITHIN THE UK PRIME MINISTER QUESTION TIME DISCOURSE (09.04.2019)
}

The following work deals with the investigation of the expressive means and stylistic devices used by the UK Prime Minister Boris Johnsons within the Question Time of the UK Prime Minister discourse, 09.04.19, with the purpose to discredite the leader of the Labour Party Jeremy Corbyn or the the Labour Party as a whole. It is pointed out that the Question Time of the UK Prime Minister discourse as a subtype of the parliamentary debates discourse is an aggressive, conflict, confronting communication with the global strategic purpose to gain and retain power and the immediate purposes to discredite opponents, to praise the allies, to make self-praising, self-presentation. The confronting nature of the Question Time of the UK Prime Minister discourse is determined by the fact of the Conservative and Labour Parties long-term struggling for power in the country. It is pointed out the that discrediting means to diminish somebody's authority, significance and importance with the aim to dominate, to be the leader, deprive opponents to be leaders. It is stated that Boris Johnsons uses the discrediting tactics "opponent is coward", "opponent is criminal", tactics of benefits, the discrediting tactics of insulting and comparison technique. It is stressed that all the used tactics and techniques are intertwined and interconnected within the given discourse and aimed either to discredite the individual or the collective opponent. It is pointed out that realization of these tactics and techniques is possible with the help of the stylistic devices and expressive means usage to provoke addressee attention to the information important for the addressor of message by appealing to the feelings and emotions of the addressee, by making the given information stressed and acute with its elements used in the unusual position. It is stated that the peculiar features of the discrediting tactics and techniques usage by Boris Johnsons within the Question Time of the UK Prime Minister discourse are the usage of a great number of stylistic devices and expressive means within the limited space of message known as constellation and the usage of the intertwined discrediting tactics and techniques within the limited space of $i t$.

Key words: stylistic devices and expressive means, discrediting tactics and techniques, Question Time of the UK Prime Minister discourse, constellation, foregrounding of information.

Problem statement. Modern society becomes more aggressive and more conflict because of lack of morality or of its low level. Confronting type of the communicative behaviour becomes norm of modern life. To dominate, to be leaders, to discredite opponents become the main purposes of any political discourse. Realization of these purposes presupposes the usage of the certain tactics and techniques. Expressive means and stylistic devices used in any type of discourse are helpful to provoke addressee attention to the ideas given in it by appealing to the feelings and emotions of addressee, by foregrounding of the information important for addressor.

Literature review. In our work we differentiate the Question Time of the UK Prime Minister discourse as a subtype of the parliamentary debates discourse, which is rather investigated [1-16]. The Question Time of the UK Prime Minister discourse as a newly differentiated discourse needs further investigation, and this fact makes the given scientific research acute.

Setting objectives. The aim of the paper is to investigate Expressive means and Stylistic devices used by the UK Prime Minister Boris Johnsons during his answering questions of the UK MPs on the 4-th of September, 2019 with the aim to discredite opponents - the Conservative Party. Method of simple calculation, discourse analysis method, method of immediate constituents, pure sampling and comparative method are used to realize the aim of the given work.

The material of the article. The Question Time of the UK Prime Minister (PMQs) is known as an official process of the UK political life. During the period of half of an hour each Wednesday from 12.00-12.30 p. m. the UK Prime Minister (PM) answers questions of the MPs (members of UK Parliament) in the House of Commons 
of the UK Parliament. The process of the Question Time of the UK Prime Minister is broadcasted by radio, $\mathrm{TV}$, internet and receives its full transcription in the UK Parliament edition Hansard.

In our work we determine the Question Time of the UK Prime Minister discourse as a subtype of the parliamentary debates discourse with the features of the political [10, p. 22-28; 9, p. 44] and institutional [4, p. 37-64] discourses.

It is stated that any political discourse, and the Question Time of the UK Prime Minister as part of it, is an aggressive, conflict, confronting communication. With the global strategic purpose to gain and retain power it has the immediate purposes: 1) to discredite opponents; 2) to praise the allies; 3 ) to make self-praising, self-presentation [8, p. 11]. We consider that the process of discrediting opponents and of self-praising, self-presenting presuppose the presence of both of them.

It's known that discrediting means to diminish somebody's authority, significance and importance $[8$, p. 21]. Any communication based on the discrediting of the opponent communicators is a conflict, aggressive and confronting communication, the aim of which is to dominate, to be the leader, deprive opponents to be leaders.

We can state that the confronting nature of the Question Time of the UK Prime Minister discourse is determined by the fact of the Conservative and Labour Parties long-term struggling for power in the country.

Within the period of 19.04.2019, the UK Government runs by the Conservative Party with Boris Johnsons at the head, the Opposition is represented by the Labour Party with Jeremy Corbyn at the head. So, the House of Commons becomes an arena of Parties' struggling, fighting for power in the country [13, p. 209; 9, p. 20].

Moreover, we can state that the Question Time of the UK Prime Minister in the House of Commons resembles the fight, the battle between the UK Prime Minister and the MPs from the competitive Party to discredit each other by appealing to the values and wishes, emotions and feelings of the people of the UK community.

In our work we determine the individual opponent (the leaders of the parties, the members of the parties) and the collective opponent (the competitive party as a unity).

In this case, the discrediting tactics within the Question Time of the UK Prime Minister discourse is aimed to discredite, to diminish the importance and value either of the of the individual opponent (leaders and members of the competitive parties) or of the collective opponent (competitive party).

We can state that he discrediting individual opponent tactics prevails within the Question Time of the UK Prime Minister discourse.

The analysis of the Question Time of the UK Prime Minister discourse makes it possible differentiate the following discrediting tactics used by the UK Prime Minister Boris Johnsons: 1) tactics dealing with the opponent negative features based on the opponent system of values; 2) discrediting tactics referring also to the self-presenting tactics and 3) insulting technique.

We 'd like to add that this differentiation into several types of the discrediting tactics is nothing but our attempt to module, to make order, to classify. In reality, in real discourse, these tactics are not given in pure forms, they are intertwined, interconnected, so it is even difficult to separate one from another. In reality, in real discourse, all the tactics are organized with the main purpose - to discredite the opponent.

The analysis of the Question Time of the UK Prime Minister discourse shows that to diminish the valuable essence of the opposite Labour Party and its leader Jeremy Corbyn the UK Prime Minister Boris Johnsons uses such discrediting tactics dealing with the opponent negative features based on the opponent system of values as: a) opponent is coward; b) opponent is criminal.

In order to realize his plans to discredite opponents the UK Prime Minister Boris Johnsons uses a set of language units in the form of Stylistic devices and Expressive means, the aim of which is to provoke and arrest the addressee attention by influencing the emotions and feelings of addressee, by foregrounding information important for the addressor.

It's known that realization of the discrediting tactics is concerned with the usage of the language units with negative meaning. Repetition of the language units with the idea "to be coward": to be frit, to be frightened, dither and delay, surrender Bill makes it possible to stress this idea of being coward and to provoke addressee attention to this idea, which Boris Johnsons associates with Jeremy Corbyn - the leader of the Labour Party, and as a result to realize his discrediting opponent tactics "opponent is coward".

We can state that usage of the Parallel Constructions of the anaphoric model in the form of a question and answer for them in a form of nominative sentence with the same idea "to be coward" - Dither and delayon the groundings of two-membered sentences makes the given message informationally and emotionally tensed and stressed: 
What are they supposed to chant? What is the slogan? "What do we want? Dither and delay [17].

The emotional colouring of the given part of the message is also intensified by the attempt of Boris Johnson to use this question-answer form to create the atmosphere of natural communication in the form of dialogue. The discrediting tactics here is doubled with the manipulative one, when the answers for the given questions are given ready-made by the same person who puts these questions.

Moreover, according to the norms of communication during the Question Time of the UK Prime Minister, Boris Johnsons is oriented to answer the MPs questions without putting his own. But he uses a lot of question forms which is impossible to answer, making these questions similar to rythorical questions:

Can he confirm now that he will allow the people of this country to decide on what he is giving up in their name with a general election on 15 October? Or is he frit? [17].

We can state that emphatic sentences are used by Boris Johnsons to make his message emotionally coloured, to pay attention of the addressee to the given information as part of his discrediting tactics realization:

The only thing standing in our way is the undermining of our negotiations by this surrender Bill, which would lead to more dither and delay. We delayed in March; we delayed in April; and now the right hon. Gentleman wants to delay again for absolutely no purpose whatever [17].

Thegivenexampledemonstratestheconglomeration of the Stylistic devices and Expressive means known as constellation, when within the limited space of message the addressor uses a great number of the Stylistic devices and Expressive means to realize his/her plans to influence the addressee.

We can state the constellation is a peculiar feature of the Boris Johnsons message with his intention to discredite opponents: usage of the emphatic sentence "The only thing standing...", parallel constructions with the repeated "We delayed", repetitions delay, surrender Bill, dither and delay, which are repeated several times within the given message by Boris Johnsons.

Irony is also used by Boris Johnsons to discredite Jeremy Corbyn, when the word combination a straight face, which normatively has positive meaning, within the given message has contextually opposite meaning. In other words, it means "dishonest". The meaning of it is intensified on the basis of words used in the sphere of law: accuse, scrutiny, Bill, verdict, and the words with the meaning "to be coward": frit, frightened:

I really do not see how with a straight face the right hon. Gentleman can accuse anybody of being unwilling to stand up to scrutiny when he will not agree to submit his surrender Bill to the verdict of the people in an election. He is frit; he is frightened [17].

To realize his discrediting tactics of different types Boris Johnsons uses parenthetical sentences and detachments to express his attitude to the given information, to give some additional information to the described facts:

1) If this Bill is passed this afternoon - I do not want an election, and I do not think that the right hon [17].

2) I am proud to say that those on the living wage are now taking home $£ 500$ more every year than they were in 2010, thanks to this Conservative Government [17].

So, the parenthetical sentences "I do not want an election" contains Boris Johnsons negative attitude to the Bill of the Conservative Party to organize general elections (the second referendum) on the problems of Brexit. The detachment thanks to this Conservative Government gives opportunity for Boris Johnsons to realize his discrediting tactics of benefits demonstrating the advantages of the Conservative Party, self-praising themselves and diminishing the valuable essence of the competitive party the Labour Party.

Within the given first example we can also observe transposition of the compound sentence into complex one when the main clause is transformed into the coordinative sentence with the conjunction and: ... and I do not think that the right hon. This unusual form of the sentence has the effect of unexpected defectency which is able to strike addressee.

We can state that the UK Prime Minister Boris Johnsons uses a lot of intensifiers to intensify the meanings of word, ideas and to make his message more coloured and emotionally stressed:

1. Let us be absolutely clear [17].

2. Gentleman knows very well, you do not negotiate in public [17].

With the same purpose to intensify the meanings of word, ideas and to make his message more coloured and emotionally stressed, Boris Johnsons uses the degrees of comparison:

1. Gentleman is guilty of the most shameless scaremongering [17].

2. Gentleman is recommending is yet more dither, yet more delay and yet more uncertainty for business [17]. 
The superlative degree of the adjective "shameless" in the form of the most shameless with the combination of word with negative meaning guilty and with the combination of the word scaremongering in the meaning "to be coward" and comparative degree more with the combination of the words dither, delay, uncertainty with the idea "to be coward" are used to discredite the leader of the Labour Party Jeremy Corbyn as a coward person.

To realize his tactics "opponent is criminal" the UK Prime Minister Boris Johnsons uses language units with the meaning "criminal": mobs of Momentum activists, Carakas.

The usage of metaphor to paralyse the traffic with the language units with the meaning "mafia" mobs of Momentum activists is able to strike addressee by appealing to the addressee's feelings and emotions:

He is asking for mobs of Momentum activists to paralyse the traffic [17].

The peculiar feature of Boris Johnsons message is not only constellation but also interconnection of several discrediting tactics within the limited space of message that makes the given information vivid, acute, emotionally coloured and stressed:

The contrast could not be clearer: we think that the friends of this country are to be found in Paris, in Berlin and in the White House, and he thinks that they are in the Kremlin. in Tehran and - [Interruption.] He does. And in Caracas - and I think he is "caracas"! [17].

The material of the given message extract by Boris Johnsons is based on the constellation of the Stylistic devices and Expressive means within the intertwined discrediting tactics of "opponent is criminal", insulting technique, comparison technique.

So, within the given example we can observe irony "The contrast could not be clearer" with the contextual meaning "The contrast is clearer", emphatic sentence He does, which make the given material extremely stressed. The usage of antitheses, given in the form of "we/I - he" opposition and opposition given in the form of the enumerated metonyms Paris, Berlin, the White House which is opposed to the other group of enumerated metonyms Kremlin, Tehran, Caracas. The first group of metonyms is associated with the authorities of the highly developed and highly civilized countries, while the authorities of the second group are located in criminal Kremlin, terroristic Tehran and mafious Caracas. All the described Stylistic devices and Expressive means are used both to realize the "opponent is criminal" tactics as well as to realize the comparison technique to discredite Jeremy Corbyn, the leader of the Labour Party.
The usage of metaphor he is "caracas within the parenthetical sentence and I think he is "caracas" is used not only to express Boris Johnsons' view point that Jeremy Corbyn has relations with the criminal structures but to insult the leader of the competitive party.

As it was mentioned above, the UK Prime Minister Boris Johnsons uses such discrediting tactics referring also to the self-presenting tactics as: a) comparison technique; b) tactics of benefits.

Comparison technique is aimed to descredite opponents by showing the advantages of themselves and disadvantages of the opponents. Realization of the comparison technique within the Question Time of the UK Prime Minister discourse is based on the antithesis, comparison and contrast:

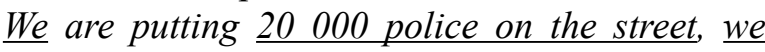
have 20 new hospital upgrades, we are growing the economy. The right hon. Gentleman, by contrast, would put a $£ 300$ billion tax on every company in the country he wants a tax on homes, and he is calling incessantly for a general strike [17].

The antithesis of the given part of Boris Johnsons message is represented by the opposition "we/I - he", by the opposition of the language units with the contextually positive (20 000 police on the street, 20 new hospital upgrades, growing the economy) and contextually negative meanings (a tax on homes, a $£ 300$ billion tax on every company in the country, a general strike). This antithesis makes it possible to discredite the competitive party by demonstrating the Conservative Party progress and the Labour Party faults.

The given information becomes more emotionally stressed and coloured with the help of the epithet usageincessantly. Parallel constructions of the anaphoric type with the repeated we and he are used by Boris Johnsons to make stress on the information relevant for him - advantages of his Conservative Party and disadvantages of the competitive Labour Party. The used detachment by contrast helps to realize the comparison technique as part of the discrediting strategy.

We can state that the UK Prime Minister Boris Johnsons uses the discrediting tactics of benefits to show pluses and strong positions of his Conservative Party. This tactics also belongs to the self-presenting tactics. So, to demonstrate the own strong positions on the basis of opponent strong positions absence means nothing but to discredite opponents.

Silence of the opponent advantages and advertising campaign of own benefits is realized by the usage of epithets, degrees of comparison in the UK Prime Minister message: 
...this Government are getting on with running a sound economy so that the poorest people in our country are seeing increases in their wages for the first time in more than a decade [17].

The epithets sound, first are used to show the Conservative Party progress in economy, and the usage of the superlative degree of comparison of the adjective "poor" in the form of the poorest, the usage of the comparative degree of the adverb more shows the increase of positive quality within the activity of the Conservative Party.

We can state that detachments are also used to realize the discrediting tactics of benifits:

I am proud to say that those on the living wage are now taking home $£ 4500$ more every year than they were in 2010, thanks to this Conservative Government [17].

The usage of the detachment thanks to this Conservative Government makes it possible to show progress in life of the UK community - the living wage are now taking home $£ 4500$ more every year than they were in 2010 - as a result of the Conservative Party successful activity.

Theusage of climaxintheformofseries epithetswith the increasingly positive meaning sensible, moderate, progressive stresses the idea of the Conservative Party benefits for the UK community:

What this country needs is sensible, moderate. progressive Conservative government and to take this country out of the EU on 31 October, and that is what we are going to deliver [17].

The usage of the emphatic sentence "...that is what we are going to deliver", which is also used as parallel construction to the other parallel construction of the same structure "What this country needs...", stresses the idea of the Conservative Party benefits for the UK community.

Moreover, the idea of the of the Conservative Party benefits for the UK community is doubled by the fact that the given information is pronounced by Boris Johnsons at the end of his message, where the final position of any message is of great importance to provoke addressee attention, to strike addressee.

We can state that the UK Prime Minister Boris Johnsons uses the discrediting tactics of insulting to discredite the competitive party and its leader Jeremy Corbyn by using a number of metaphors.

He uses the tactics of insulting 5 times: 4 times to insult the leader of the Labour Party Jeremy Corbyn and one time to discredite the Labour Party as a whole.

To insult the leader of the Labour Party Jeremy Corbyn Boris Johnsons uses such metaphors as:

1. Gentleman is worried about free trade deals with America, but I can see only one chlorinated chicken in the House, and he is sitting on the Opposition Front Bench [17].

2. ... and I think he is "caracas"! [17]

3. He is frit. (2 times) [17].

To insult and to descredite all the members of the Labour Party Boris Johnsons uses such metaphor as:

The shadow Education Secretary says that Labour's economic policy is - and I quote, by your leave, Mr Speaker, - "shit-or-bust"; I say it is both [17].

The usage of metaphors makes it possible to transfer the qualities of one object to another one, but this transference is given in insulting manner. The user of this tactics should realize the result of it - either the insulting feedback, or the physical fight, physical attack from the opposite side. Within the House of Commons physical fight is impossible, insulting feedback is normative.

To sum up the material we can state that to diminish the valuable essence of the opposite Labour Party and its leader Jeremy Corbyn, the UK Prime Minister Boris Johnsons uses the discrediting tactics "opponent is coward", "opponent is criminal", tactics of benefits. the discrediting tactics of insulting, comparison technique. Realization of these tactics and techniques is possible with the help of the Stylistic devices and Expressive means usage to provoke addressee attention to the information important for addressor of message.

To realize his plans to discredite the leader of the Labour Party Jeremy Corbyn and the competitive party as a whole the UK Prime Minister Boris Johnsons uses a set of the Stylistic devices and Expressive means: metaphors, epithets, metonyms, detachments, parenthetic sentences, nominative sentences, emphatic sentences, parallel constructions, enumerations, repetitions, climax, transposition of the subordinate clause into coordinate one, transposition of the questions into rythorical ones, degrees of comparison, antithesis, irony.

Conclusions. Summing up the material, we can state that realization of the UK Prime Minister Boris Johnsons' plans to discredite the leader of the competitive Labour Party Jeremy Corbyn and the party as a whole during the Question Time of the UK Prime Minister is possible by his successful implementation of a number of the discrediting tactics and techniques. All the discrediting tactics and techniques used by Boris Johnsons within the Question Time of the UK Prime Minister discourse are intertwined, interconnected.

Realization of the discrediting tactics and techniques presupposes the usage of the Stylistic devices and Expressive means to provoke addressee 
attention to the information imporant for the addressor of message by appealing to the feelings and emotions of addressee, by making this information stressed.

The peculiar features of the discrediting tactics and techniques usage by Boris Johnsons within the Question Time of the UK Prime Minister discourse are the usage of a great number of Stylistic devices and Expressive means within the limited space of message known as constellation and the usage of the intertwined discrediting tactics and techniques within the limited space of it.

It is perspective to investigate the realization of the discrediting tactics and technique used by the MPs form the Opposition with the Jeremy Corbyn at the head within the Question Time of the UK Prime Minister discourse.

\section{References:}

1. Басюк Л. М. Дебати в парламентському дискурсі Великої Британії і США: лінгвопрагматичний аспект : автореф. дис. ... канд. філол. наук : 10.02 .04 ; Київський університет імені Бориса Грінченка. Київ, 2019. $20 \mathrm{c}$.

2. Дьяченко Н. М., Халін В. В. Комунікативні стратегії в сучасному українському політичному дискурсі. Вісник Житомирського державного університету імені Івана Франка. Серія «Філологія». 2019. № 1(89). C. 56-62.

3. Зернецька О. В., Зернецький П. В. «Чи прийме парламент нашу подяку?» Дещо про мовний вишкіл британських парламентарів. Віче. 2004. № 9. С. 73-74.

4. Карасик В. И. Этнокультурные типы институционального дискурса. Этнокультурная специфика речевой деятельности : сборник обзоров. Москва : ИНИОН РАН, 2000. С. 37-64.

5. Крячкова А. П. Лингвопрагматические средства реализации вербальных атак на имидж политических партий Германии : дисс. ... канд. филол. наук : 10.02.04 ; Московский гос. ин-т международных отношений. Москва, 2019. 170 с.

6. П'єцух О. І. Емотивність політичного дискурсу парламентських дебатів у Сполученому Королівстві. Науковий вісник Міжнародного гуманітарного університету. Серія «Філологія». 2016. № 25. T. 2. С. 103-105.

7. П'єцух О. І. Нормативність політичного дискурсу парламентських дебатів у Сполученому Королівстві Великої Британії та Північної Ірландії. Science and Education a New Dimension. Series "Philology". 2017. Vol. 31. Iss. 118. P. 61-64.

8. Руженцева Н. Б. Дискредитирующие тактики и приемы в российском политическом дискурсе : монография. Екатеринбург : Уральский гос. пед. ун-т, 2004. 294 с.

9. Рябоконь Г. Л. Дискурсивні особливості інтернет-публікацій дебатів британського парламенту : дис. ... канд. філол. наук : 10.01.08 ; Національний університет «Києво-Могилянська академія». Київ, 2009. 276 с.

10. Шейгал Е. И. Структура и границы политического дискурса. Филология. Краснодар, 1998. № 14. C. 22-29.

11. Coxall B., Robins L. Contemporary British Politics. New York : Palgrave Macmillan, 1994. 509 p.

12. Coxall B., Robins L., Leach R. Contemporary British Politics. New York : Palgrave Macmillan, 2003. 452 p.

13. Forman F. N., Baldwin N. B. Mastering British Politics. Basingstoke : Macmillan, 1996. 478 p.

14. Humeniuk N. H. Pragma-communicative aspects of the Boris Johnson' first speech as a Prime Minister (July, 24, 2019). Закарпатські філологічні студії. 2019. Вип. 12. С. 68-74.

15. Humeniuk N. H. Stylistic aspect of the Boris Johnsons' ideological discourse of his first speech as a Prime Minister, 07.24.19. Науковий вісник Дрогобицького державного педагогічного університету імені Івана Франка. Серія «Філологічні науки (мовознавство)». 2019. № 12. С. 39-42.

16. Humeniuk N. H. Storytelling technique in the Boris Johnsons' first speech as a Prime Minister, 07.24.19. Вчені записки Таврійського начіонального університету імені В. І. Вернадського. Серія «Філологія. Соціальні комунікації». 2019. Т. 30(69). № 4. Ч. 2. С. 32-35.

17. Parliament UK. Commons. Debates, 04 September 2019. Hansard. 2019. URL: https://hansard.parliament. uk/commons/2019-09-04/debates/917B81A6-57F8-48C3-AABE-63224897F16E/Engagements.

\section{ГУМеНюК Н. Г. СТИЛІСТИЧНИЙ АСПЕКТ РЕАЛІЗАЦЇ̈ БОРИСОМ ДЖОНСОНОМ ТАКТИКИ ДИСКРЕДИТАЦІЇ ОПОНЕНТА В МЕЖАХ ДИСКУРСУ ВІДПОВІДІ НА ЗАПИТАННЯ ПРЕМ'ЄР-МІНІСТРОМ СПОЛУЧЕНОГО КОРОЛІВСТВА В ПАРЛАМЕНТІ (04.09.2019)}

Подана робота присвячена дослідженню використаних Борисом Джсононом стилістичних прийомів i засобів у межсах дискурсу відповідей на запитання Прем'єр-міністром Сполученого Королівства в парламенті від 4 вересня 2019 р. $з$ метою дискредитувати лідера Лейбористської партії Джеремі 
Корбіна або Лейбористську партію загалом. Вказується, що дискурс відповідей на запитання Прем'єрміністром Сполученого Королівства в парламенті як підтип дискурсу парламентських дебатів $\epsilon$ агресивною, конфліктною, конфронтуючою комунікацією з глобальною стратегічною метою, що полягає в отриманні й утриманні влади, $i$ з безпосередніми иілями дискредитації опонентів, похвали союзників, самовихвалення, самопрезентації. Конфронтуюча природа дискурсу відповідей на запитання Прем'єр-міністром Сполученого Королівства в парламенті визначена фактом тривалої боротьби між Консервативною та Лейбористською партіями за владу в крайні. Вказується, що «дискредитувати» означає «зменшити чийсь авторитет, значимість, важливість із метою свого домінування, з метою бути лідером та позбавити опонента можливості бути лідером». Стверджсуться, щзо Борис Джонсон використовуе дискредитуючі тактики «опонент - боягуз», «опонент - кримінальний елемент», тактику переваг, дискредитуючу тактику образ та техніку порівняння. Підкреслюється, що всі використані тактики й техніки в межах поданого дискурсу є взаємопов'язаними, вони націлені дискредитувати або індивідуального, або колективного опонента. Зазначається, щро реалізація цих тактик і технік можлива за допомогою використання стилістичних засобів та прийомів із метою привернення уваги адресата до важливої для адресанта інформації за рахунок апелювання до почуттів та емоиій адресата, подання иієї інформачії як напруженої й гострої з ї̈ елементами в незвичайних позиціях. Стверджується, що особливостями використання Борисом Джонсоном дискредитуючих тактик $i$ технік у межах дискурсу відповідей на запитання Прем'єр-міністром Сполученого Королівства в парламенті є використання великої кількості стилістичних засобів та прийомів в обмеженому просторі повідомлення, відомого як констеляція, а також використання в обмеженому просторі повідомлення переплетених і взаємопов'язаних дискредитуючих технік та тактик.

Ключові слова: стилістичні засоби та прийоми, дискредитуючі тактики й техніки, дискурс відповідей Прем'єр-міністром Сполученого Королівства в парламенті, констеляиія, висування інформаиії. 